\title{
A classification of semi-natural northern prealpine river stretches based on chironomid communities
}

\author{
C. Orendt
}

Orendt Hydrobiologie WaterBioAssessment, Steinstr. 37, 04275 Leipzig, Germany. E-mail: orendt@t-online.de

\begin{abstract}
Using cluster analysis, ecological profiles of the species, and the (Diamesinae + Orthocladiinae) / Chironominae ratios, prealpine rivers were classified by their chironomid communities based on 338 species: (1) summer-cold mountain rivers (Isar, Salzach, Inn/Mühldorf), (2) summer-warm moraine-stretches (Würm, Alz/moraine rupture, Amper, Altmühl), (3) the summerwarm lowland river Upper Alz (lake outlet and the stretch to Altenmarkt village), (4) the lower section of the river Inn regulated by dams, which is dominated by a littoral community. The river Upper Alz is faunistically differentiated along it's course. Classification of river stretches is predominantly explained by rhithral and eurytope species. Potamal and littoral species had no effect on classification. The results suggest that water temperature is the most important factor of the chironomid-based river classification, which is in harmony with studies by Rossaro (1992) and Lindegaard \& Brodersen (1995). Locally, other morphological parameters as reach slope and substrate may be important factors as well. However, further data are needed to clarify their role in species distribution.
\end{abstract}

Keywords : Chironomidae, classification, rivers, reference conditions, stream sections.

\section{Introduction}

Nearly all rivers in the Alps are regulated by power plants. Therefore, long river stretches in the prealpine region are impacted, affecting river morphology, and, c on s e que n $\mathrm{t} l \mathrm{y}$, the downstream system including the floodplain. For instance, the River Lech in its German section was transformed into a chain of reservoirs and thus lost the characteristics of a typical gravel-rich alpine river. The River Lower Inn was modified in a similar manner. In the river Salzach, however, such destruction did not occur in wider extents at present preserving the conditions of a semi-natural prealpine river in Germany. However, a disturbance of the free hydrological dynamics must be assumed in the latter as well, at least for the Austrian part of the river. In the Alpine region, only wider sections of the River Tagliamento in Friuli (Italy) can be considered as non-impacted (Lippert et al. 1995, Arscott et al. 2000).

The morphological degradation of the natural river landscape causes a decrease in the taxonomic diversity of their communites. A documentation and reconstruction of the undisturbed community is not only of histo- rical interest, but can also be the necessary reference to elucidate how far the impacted state differs from the natural one. Ecological reference conditions would enable us to control effectively the quality and extents of (1) impacts on the river systems and (2) their revitalisation, as required by the Water Framework Directive of the European Community.

This paper is a contribution to the natural classification of northern prealpine rivers by river biota, using, as far as possible, those reaches still unimpacted. To this end, the species of the family Chironomidae (Diptera) are particularly suitable indicators and reflect the biodiversity of complex river systems (e.g. Garcia \& Laville 2001). Chironomid species assemblages are able to characterise changes in the ecological status of waters (see e.g., Wilson \& Bright 1973, Wilson \& McGill 1977, Wilson 1980, Fittkau et al. 1992, Orendt 1999). In the meantime, several studies on the chironomid fauna in northern prealpine stretches differing in physiography were performed, however, some remained unpublished. The data of these surveys, which comprise 338 taxa as a total, were now evaluated using 
statistical methods. In particular, I sought to work out (1) whether and how the selected stretches of the prealpine rivers studied could be classified by chironomid communities, and (2) which species mostly contributed to the classification.

\section{Study area}

The prealpine region is confined by the northern edge of the Alps (in the south), the Swiss Jurassic (southwest), the Swabian-Franconian Alb (north) and the Bohemian mass (east). It contrasts clearly from the surrounding mountains by its lower elevation. On one hand, it represents a deposition zone for eroded material from the mountains, on the other hand, it is an erosive zone, as it was elevated successively since the miocene period.

Apart from the data of the rivers listed in Table 1, a brook from a floodplain in northern Nuremberg, the Gründlach brook (Orendt et al. 2000), was also included in the analysis in order to find out whether and to what extent a prealpine river community differs from that of a small stream in plains. The stretches of the Rivers Salzach, Würm, Amper and Upper Alz surveyed were considered as not impacted by river regulation, and hydrologically undisturbed. The stretches of the
Inn (Mühldorf) and Isar studied are reduced in their natural discharge for energy production and flood-protection. The former can be regarded as semi-natural with respect to river morphology, the latter is partly regulated. The studied section of River Isar flows in the furcation zone. However, the bed is reduced in its extent and is far from its natural state, which, for example, can be found at the River Tagliamento (northern Italy, Lippert et al. 1995). However, as far as I know, only scattered data are available on the chironomid communities from this river (Kretschmer 1995).

For data evaluation, the Upper Alz has been divided into two sections (Marg r e i t e r-Kownacka 1993: lake outlet and rest of the stretch) or in three sections (Caspers 1983, Schadhauser 1989: lake outlet, stretch near Höllthal village, moraine section near Altenmarkt village). Division was based on the morphological characteristics of the landscape. For example, the reach slope in the section upstream Altenmarkt is less than $1 \%$, whereas it increases to $25 \%$ in the moraine section, which has a remarkable effect on hydrodynamic processes. The stretch of the Lower Inn is heavily modified by a chain of reservoirs. Therefore, the potamal character, which can be assumed under natural conditions, is morphologically strongly degraded.

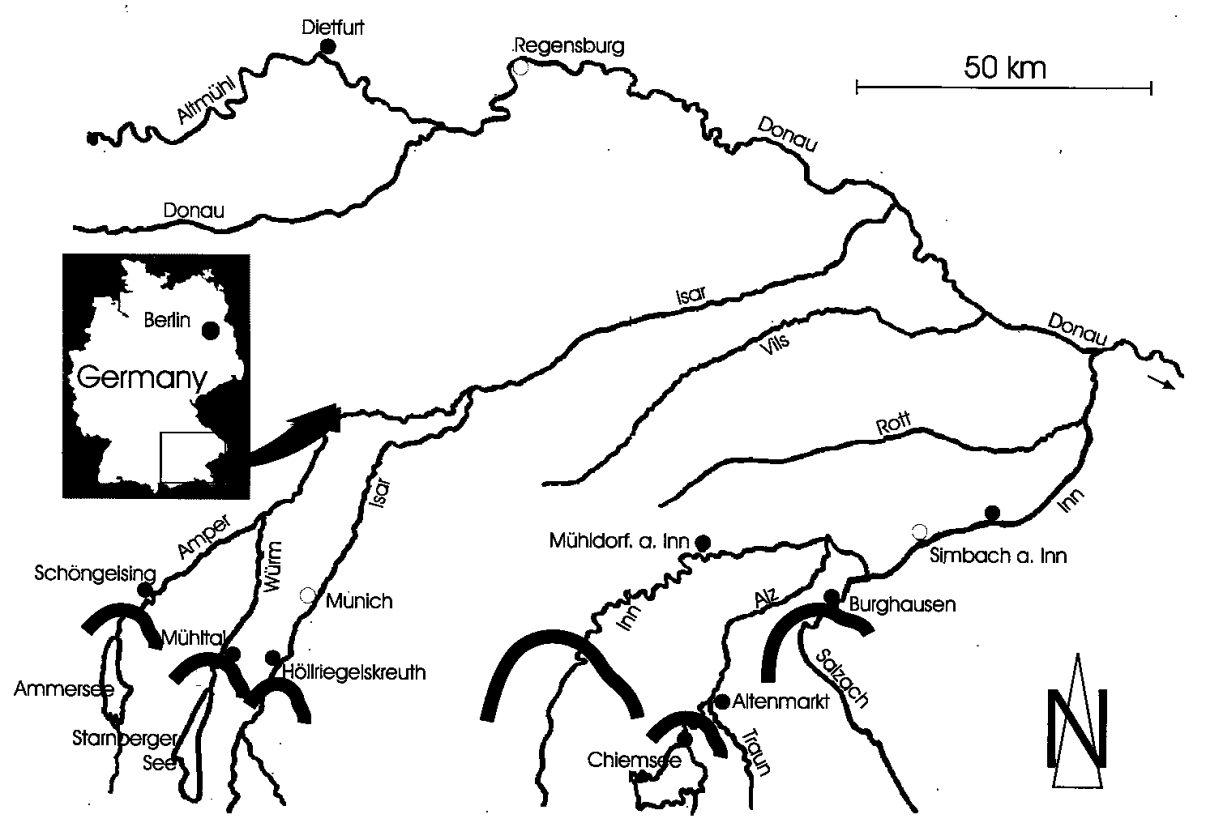

Fig. 1. River sections studied (black dots) and indication of moraine ruptures. 


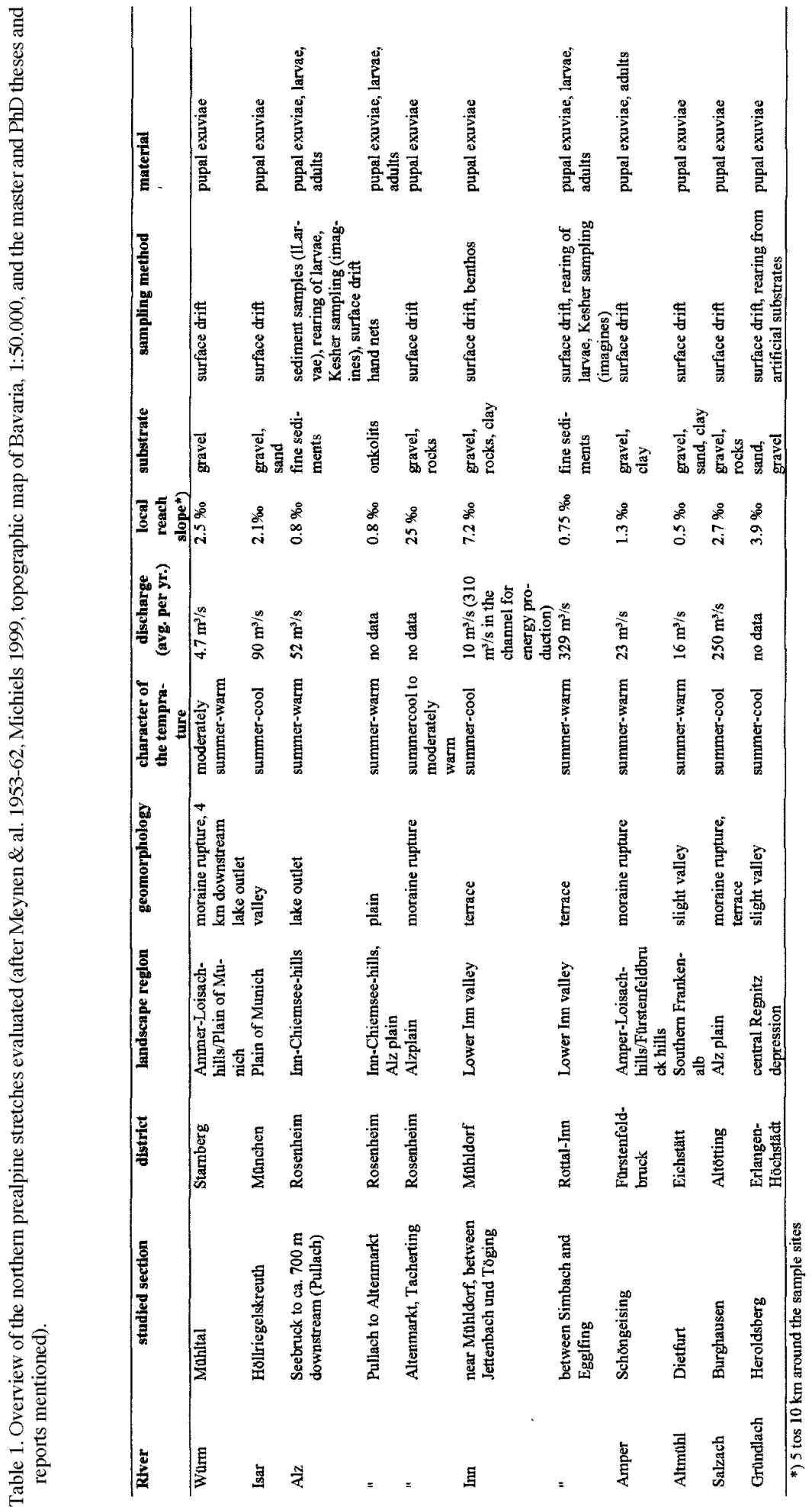




\section{Methods}

For the classification, the combined chironomid record lists of the river stretches studied were used as a matrix (Table 4). The sampling methods providing adults, pupal exuviae and larvae, respectively, differed between the studies. For adults, light traps and hand nets, for pupal exuviae, hand nets and Brundin drift nets, for larvae, surber sampler and hand nets were used. The available material is listed in Table 1. Details are given by the authors listed in Table 2. As scaling for abundance was not the same in the various studies, abundance was transformed to presence/absence format in order to make the data comparable. Before processing, the record lists were checked for synonyms and doubtful identifications were eliminated. The data analysis comprised the following steps:

- For the classification of river stretches, a hierarchical cluster analysis was performed. Species found at one or at more than nine sites were excluded. Therefore, the number of the species included for processing was $\mathrm{n}=$ 194 (out of 338 taxa recorded from all rivers considered). The River Alz was differentiated into «lake outlet», «upper stretch (river)» and «moraine rupture».

- In a second step, the chironomid species were preclassified according to their main distribution within the river continuum («crenal», «rhithral», «potamal», «littoral», «profundal», «eurytope», «not categorized») according to the classification lists of Moog et al. (1995) and Schmedtje \& Colling (1996). This was done to prepare the next step of the analysis. The categorization criterion was that a species appeared with $\geq 6$ of 10 possible value points within a river zone, using the ecological species profiles listed by the authors mentioned. Those species which did not reach $\geq 6$ points in either of these zones were put in the cate- gory «indifferent», as they were not bond to a certain zone. «Not categorized» comprised species which were not mentioned in either of the lists.

- In a third step, for each of the river continuum categories, separately, a cluster analysis was performed (similarity measure after Van der Mareels; clustering method: minimum variance clustering; after Wildi \& Orloci 1986), except for the crenal and profundal species, since the species number was too low for a statistical evaluation. This was done in order to elaborate which river continuum category contributed most to the grouping results of the former cluster analysis, in which the species of all categories had been included.

- In a fourth step, the distribution of all species found in a stretch (here, single records were included) with respect to their river continuum categories and to their feeding type categories were analysed according to the ecological species profiles listed by Moog et al. (1995) and Schmedtje \& Colling (1996). This was performed to elaborate the river-specific community profile.

- Finally, the ratio (Diamesinae + Orthocladiinae) / Chironominae was calculated for each river stretch in order to indicate and test plausibility of the river-specific continuum profile with another approach. General$1 \mathrm{y}$, in rhithral zones, the species of the Diamesinae + Orthocladiinae dominate the community (high index values), whereas in potamal and littoral zones the Chironomini species are predominant (low index values).

\section{Results}

\section{Classification of the river stretches}

The cluster analysis showed five clearly diff e $\mathrm{r}$ e $\mathrm{n} \mathrm{t}$ groups of stretches (Fig. 2): Upper Alz (survey of Caspers 1983), Upper Alz (survey of Margreiter-Kownac-

Table 2. (Diamesinae + Orthocladiinae) / Chironominae species ratios of the stretches evaluated.

\begin{tabular}{lcll}
\hline river & $\begin{array}{c}\text { (Diam.+ Orth.) } \\
\text { /Chir. }\end{array}$ & reference & material \\
\hline Inn/ Mühldorf & 4.3 & Orendt (1999) & larvae, pupal exuviae \\
Alz/moraine & 2.8 & Schadhauser (1989) & pupal exuviae \\
Isar & 2.3 & Schröder (1993) & pupal exuviae \\
Upper Alz & 1.8 & Margreiter-Kownacka (1993) & larvae, pupal exuviae \\
Würm & 1.5 & Wyrwa (1987) & pupal exuviae \\
Altmühl & 1.5 & Gmelch (1986) & pupal exuviae \\
Gründlach & 1.3 & Orendt et al. (2000) & pupal exuviae \\
Upper Alz (lake outlet) & 0.8 & Caspers (1983) & adults \\
Amper & 0.6 & Reiss (1984) & pupal exuviae, adults \\
Lower Inn & 0.5 & Reiss \& Kohmann (1982) & larvae \\
\hline
\end{tabular}




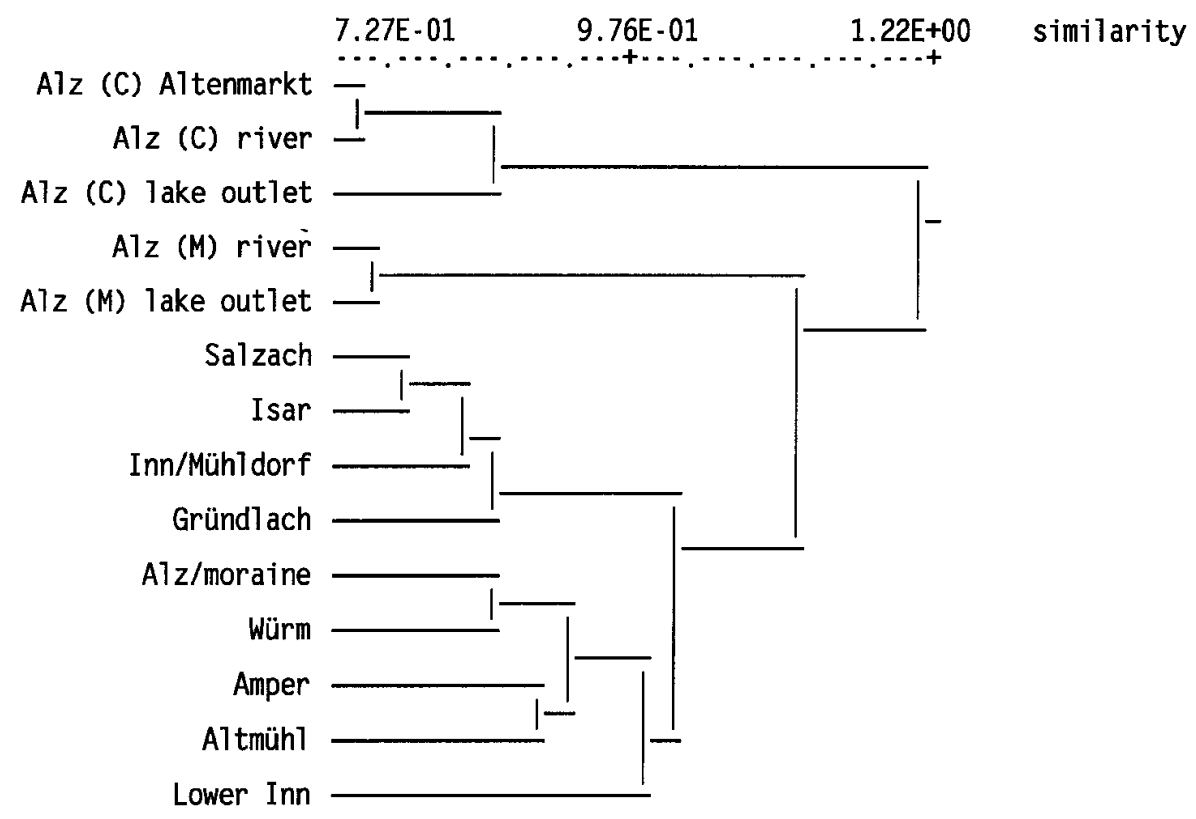

Fig. 2. Cluster analysis of the river stretches based on the chironomid communities $\left(n=194 ;\left(\chi^{2=756,19 ;}\right.\right.$ $\mathrm{C}=0.212) ;(\mathrm{M})=$ Margreiter-Kownacka (1993), (C) = Caspers (1983).

ka 1993), Salzach (Isar und Inn/Mühldorf ), Alz/moraine (Altmühl, Amper, Würm), and Lower Inn. The sections of the Upper Alz between lake outlet and moraine were similar in their faunistic communities, but also clearly differentiated. However, the surveys of Caspers (1983) and Margreiter-Kownacka (1993) differed distinctly. The River Altmühl and the group of the moraine rupture reaches showed the lowest similarity. The community of the Gründlach brook from the slightly hilly region was nearest to Salzach, Isar and Inn (Mühldorf). The evaluation according to the distribution of the species in the river continuum provides more precise information on the character of the differences (for selected stretches, see results in Figs. 3a, $3 b)$ :

(1) Isar, Salzach, Inn (Mühldorf) and Alz/moraine show a rhithral character accentuating the hyporhithral. Potamal and littoral proportions of the communities were less prominent.

(2) According to the data of Marg r e i t e r- K o w n a c k a (1993) the Chiemsee lake outlet (Upper Alz) represented somewhat higher littoral and potamal proportions contrasting to other river sections downstream and reflecting the effect of the lake and the small reach slope upstream. Hyporhithral species were dominant. Simi- lar percentages of the littoral and lower proportions of the rhithral were also observed in the Würm, Altmühl and the Gründlach brook.

(3) The rhithral character changes within the group of the summer-warm rivers of the moraine ruptures in «potamal» direction following the line Alz/moraine > Würm, Altmühl > Amper.

(4) Closest to the Lower Inn, the community of the Amper appeared to have highest littoral shares of the rivers studied. Epipotamal shares were dominant at this site. This tendency was indicated also in the Upper Alz surveyed by Caspers (1983).

(5) The community of the Lower Inn was dominated by littoral shares, whereas rhithral and potamal shares were low.

The ratio (Diamesinae + Orthocladiinae) / Chironominae also reflected the classification of the rivers in «predominantly rhithral» and «predominantly potamal» waters. Following this evaluation the rhithral, summer-cool stretches of Alz/moraine, Inn/Mühldorf, Isar and Salzach, can be separated from the summerwarm, potamal stretches of the Upper Alz (lake outlet), Amper and Lower Inn. Würm and Altmühl represented intermediate situations (Table 3 ). The evaluation of 

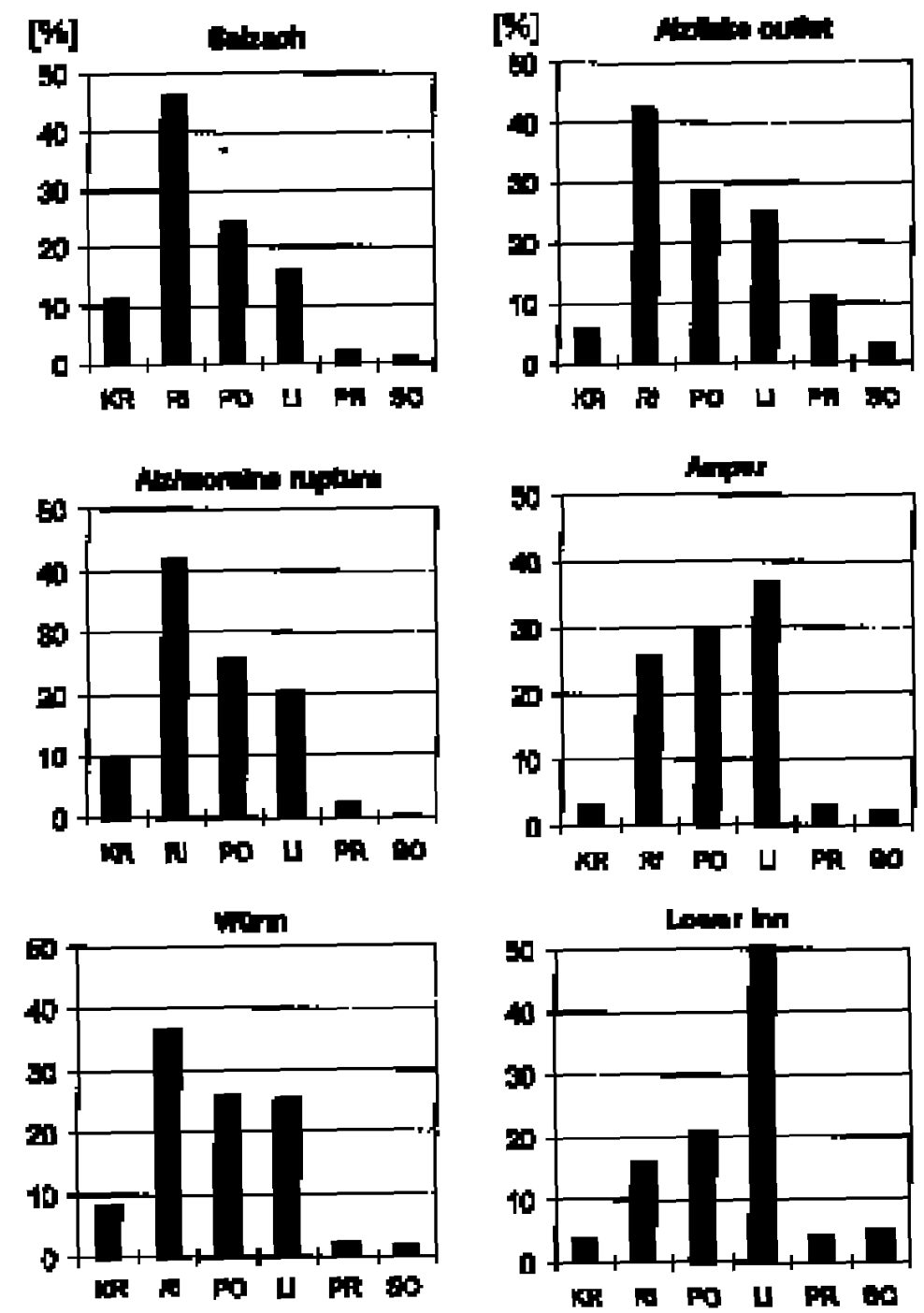

Fig. 3a. Distribution of the chironomid communities from selected prealpine river sections $(\mathrm{KR}=$ Crenal; $\mathrm{RI}=$ Rhithral $; \mathrm{PO}=$ Potamal $; \mathrm{Li}=$ Littoral: $\mathrm{PR}=$ Profundal $; \mathrm{SO}=$ Others).

the feeding types showed scrapers and sediment feeders to be dominant in all rivers (almost 30\% - 48\%). Predators were represented by $10 \%-18 \%$. In the Lower Inn, the portion of sediment feeders is quite high (48\%), the scrapers (16\%), however, comprised a smaller group than predators $(21 \%)$, which represented the highest shares in all waters studied. Filter feeders were also prominent $(10 \%)$. This distribution of the functional groups can be explained by high production and sedimentation rates in this water body regularly interrupted by dams. This littoral tendency can also be observed, to a smaller extent, in the Gründlach brook. A contrasting community was represented in the Alz/moraine rupture, where fast flowing habitats with gravel provide the highest portions of scrapers in all waters studied. 

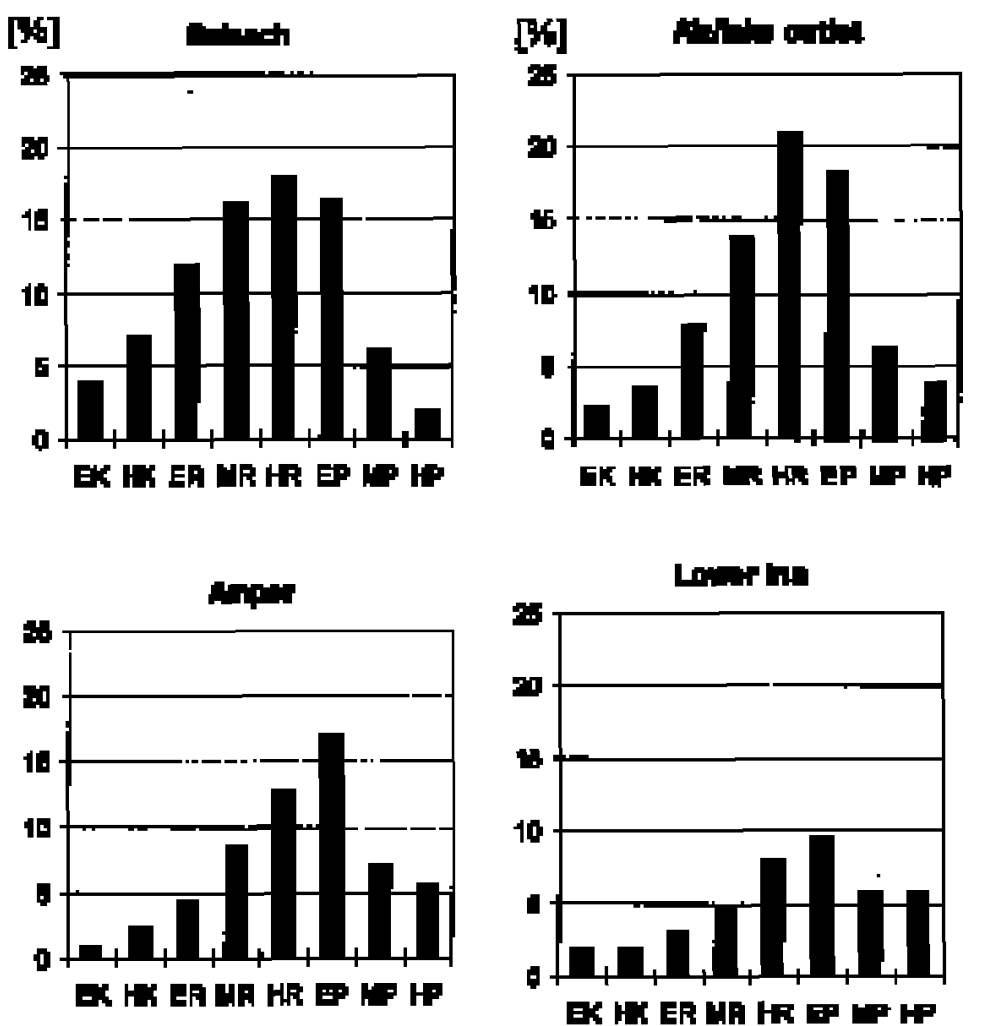

Fig. 3b. Distribution of the chironomid communities from selected prealpine river sections (only running water zones; EK = Eucrenal; HK = Hypocrenal; ER = Epirhithral; $\mathrm{MR}=$ Metarhitrhral; HR = Hyporhithral; EP = Epipotamal; $\mathrm{MP}=$ Metapotamal; HP = Hypopotamal).

Table 3. Characters of the prealpine rivers surveyed.

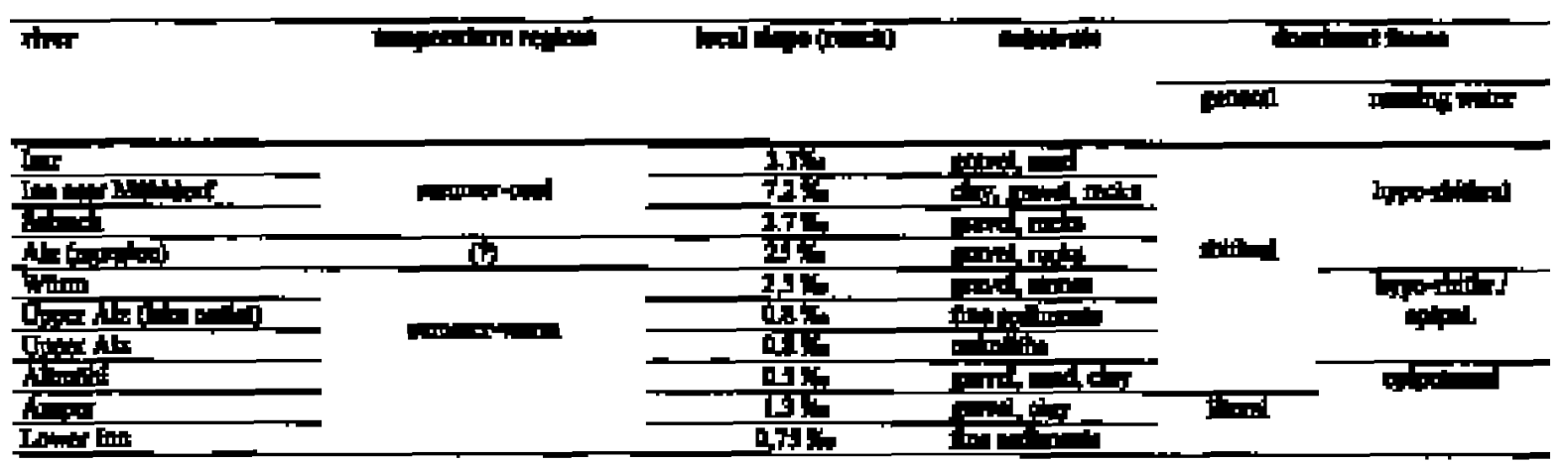


To elucidate which species were responsible for differences in the zonal categorization of rivers, species were pre-classified according to their main distribution within the river continuum (crenal, rhithral, potamal etc.) after Moog et al. (1995) and Schmedtje \& Colling (1996). Then, a cluster analysis was performed in order to elaborate faunistic similarities between the rivers. The results show that the grouping of the rivers with rhithral (Fig. 4) and eurytope taxa, respectively, harmonized fairly well with the grouping derived from the analysis with all species (not categorized before) (see Fig. 2). The groupings with other categories (potamal, crenal, littoral, not classified) were not clear (no figure). This suggests that the faunistic similarities of the rivers were based on the predominantly rhithral and eurytope species.

\section{Characteristic species}

In the following paragraphs, only the most important results of the cluster analyses of the species are presented.

The species listed below were present in all river sections evaluated. Thus, they can be considered as typical dwellers of the rhithral of prealpine rivers (on- ly species which were recorded in $\geq 2$ river stretches): Brillia bifida, Conchapelopia pallidula, Cricotopus a n n u l a to r, Cricotopus tremulus, Cricotopus trifascia, Eukiefferiella devonica, Eukiefferiella minor/fittkaui, Nilotanypus dubius, Polypedilum convictum, Tanytar sus eminulus, Thienemannimyia carnea, Tvetenia cal vescens, Tvetenia discoloripes.

In the study of Caspers (1983), some rhithral species were not recorded in the Alz, whereas Marg r e i t e rKownacka (1993) found them. The data of the latter explained a somewhat stronger rhithral character than indicated by the data of Caspers: Brillia flavifro $n s$, Diamesa tonsa/incallida, Epoicocladius ephemerae, Eukiefferiella gracei, Eukiefferiella ilkleyensis, Eu kiefferiella minor, Orthocladius frigidus, Orthocladius rivicola, Orthocladius rivulorum, Orthocladius ru bi cundus, Potthastia gaedii.

From the following list of rhithral species, no records from the Alz, only scattered records from the Würm, Altmühl and Amper, but regular records from the group «Isar/Salzach / Inn(Mühldorf)» and floodplain-brook Gründlach are documented (recorded in $\geq 2$ river stretches): Cardiocladius capucinus, Coryno neura lobata, Diamesa insignipes, Diamesa starma -

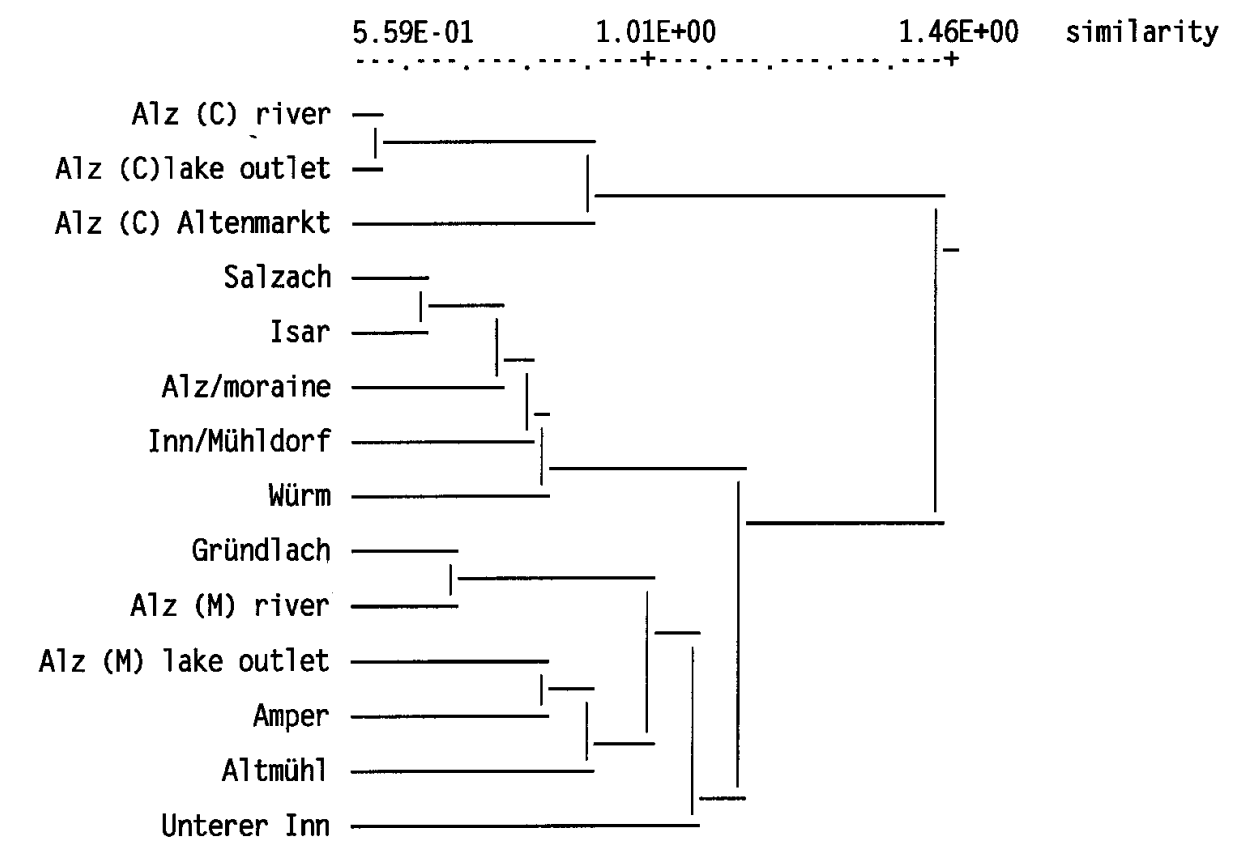

Fig. 4. Cluster analysis of the rivers using rhithral species $\left(n=46 ;\left(\chi^{2=142,319 ; C=0.267)} ;(M)=\right.\right.$ Margreiter-Kownacka (1993), (C) = Caspers (1983). 
chi, Eukiefferiella fuldensis, Eukiefferiella tiro l e $n$ s is, M i c ropsectra apposita, Odontomesa fulva, Ort ho c la dius ashei, Orthocladius luteipes, Orthocladius ru bi cundus, Orthocladius thienemanni, Paracricotopus ni $g$ e r, Paratrichocladius skirwithensis, Pseudodiamesa branickii, Rheocricotopus effuses, Rheotanytarsus c u rtistylus, Symbiocladius rh it h rogenae, Thieneman nimyia laeta, Tvetenia verralli.

The highest number of rhithral species inhabit the rivers Isar, Salzach and Inn (Mühldorf), following the Würm (20 species), Altmühl (16) and Amper (8). The River Alz is separated from the other rivers by the lack of certain rhithral species. In the Lower Inn, the only predominantly rhithral species was Odontomesa fulva.

The potamal species were separated into two groups. One group comprised species of predominantly epipotamal distribution, which were also present in the summer-warm rivers: Rheopelopia ornata, Bucho nomyia thienemanni, Rheocricotopus chalybeatus, Cricotopus bicinctus, Cricotopus triannulatus, Poly pedilum nubeculosum. The other group was represented by species less bound to a running water zone within the potamal. They were absent in the Amper, Altmühl and the sections of the Alz which was influenced by the lake outlet or lentic conditions : Car diocladius fuscus, Cricotopus albiforceps, Polypedi lum aegyptium, Rheosmittia spinicornis.

\section{Discussion}

Our results can be summed up so far: (1) Using the chironomid communities of the prealpine rivers studied so far the Rivers Isar, Salzach and Inn (Mühldorf) are comparable. Salzach and Isar turned out to be closest to the former showing a hyporhithral character. (2) The group comprising Würm, Alz/moraine, Amper and Altmühl was less close. However, the tendency to form a group cannot be overlooked. The Gründlach brook was near to this group. (3) The Alz is differentiated along its course. Lake outlet and the following section were similar to each other, but not the stretch leading through the moraine rupture. According to the data of Caspers (1983), the influence of the Lake Chiemsee on the lake outlet and the potamal character is even stronger than after Marg r e i t e r- K o w n a c k a (1993). (4) In the regulated Lower Inn, littoral species were dominant. Especially rhithral forms were absent. (5) The rhithral and not differentiated species were responsible for the faunistical classification of the river stretches compared.

The distribution pattern of chironomid species in the river sections evaluated corresponded to the physio- graphical and morphological factors of the landscape: Salzach, Isar and Inn (Mühldorf) have a comparable reach slope (2 - $3 \%$ and $7 \%$, respectively), predominantly stony or rocky substrates and cool water temperatures in summer (ca. $15^{\circ} \mathrm{C}$ ). The discharge is characterised by a pluvio-nival regime, even when power plants and dams upstream of the stretches disturb the natural dynamics. The Gründlach brook, which was included in the analysis to find the extent to which a small running water community differed from that of the rivers, has a similar reach slope $(3.9 \%$ ). From the faunistical point of view, the brook grouped with the rivers Salzach, Isar and Inn (Mühldorf). The morphological character of the lake outlet stretch of the Alz river contrasts with the rivers mentioned above in having a very slight reach slope, with a fine and biogenic calcareous sediment material (see Rott 1991) and summ e r-warm temperatures (ca. $20^{\circ} \mathrm{C}$; see Marg r e i t e rKownacka 1993). The riparian zone is broadly marked by macrophytes, which provide habitat for many littoral species. The pluvio-nival discharge regime is naturally dampened by the Lake Chiemsee and does not lead to extreme spates. The slope of the reach increases slightly towards the edge of the moraine, but the species composition does not change significantly. This, however, can be observed more clearly in the reach situated further downstream close to the moraine rupture (local reach slope $25 \%$ between the villages Altenmarkt and Tacherting). The reason for this change of species composition in the section mentioned may be the higher influence of ground water than in the lake outlet section upstream causing lower water temperatures there. This effect could also be forced by the confluence of the river Traun in this section. The Würm and Amper show a relatively high number of littoral species which is comparable to the lake outlet of the Lake Chiemsee and the floodplain-brook Gründlach. This result seems contradictory to the local morphology of the Würm and the Amper rivers (moraine ruptures). The morphology of the stretches upstream, with reduced gradient and heterogeneous land character (moorland, pond; for the Würm, possibly the lake outlet of Lake Starnberger See $4 \mathrm{~km}$ upstream), probably had some effects on the community. The number of rhithral species from the Würm, however, was similar to Alz/moraine or other rhithral rivers with stony substrate. On the other hand, the low shares of rhithral species on the Amper may reflect the reduced gradient and the summer-warm character. These two factors mentioned are prominent also in the Altmühl, where the littoral share of the community is low, but similar to the other rivers with respect to the epipotamal share. In the regulated Lower Inn, which is separated from 

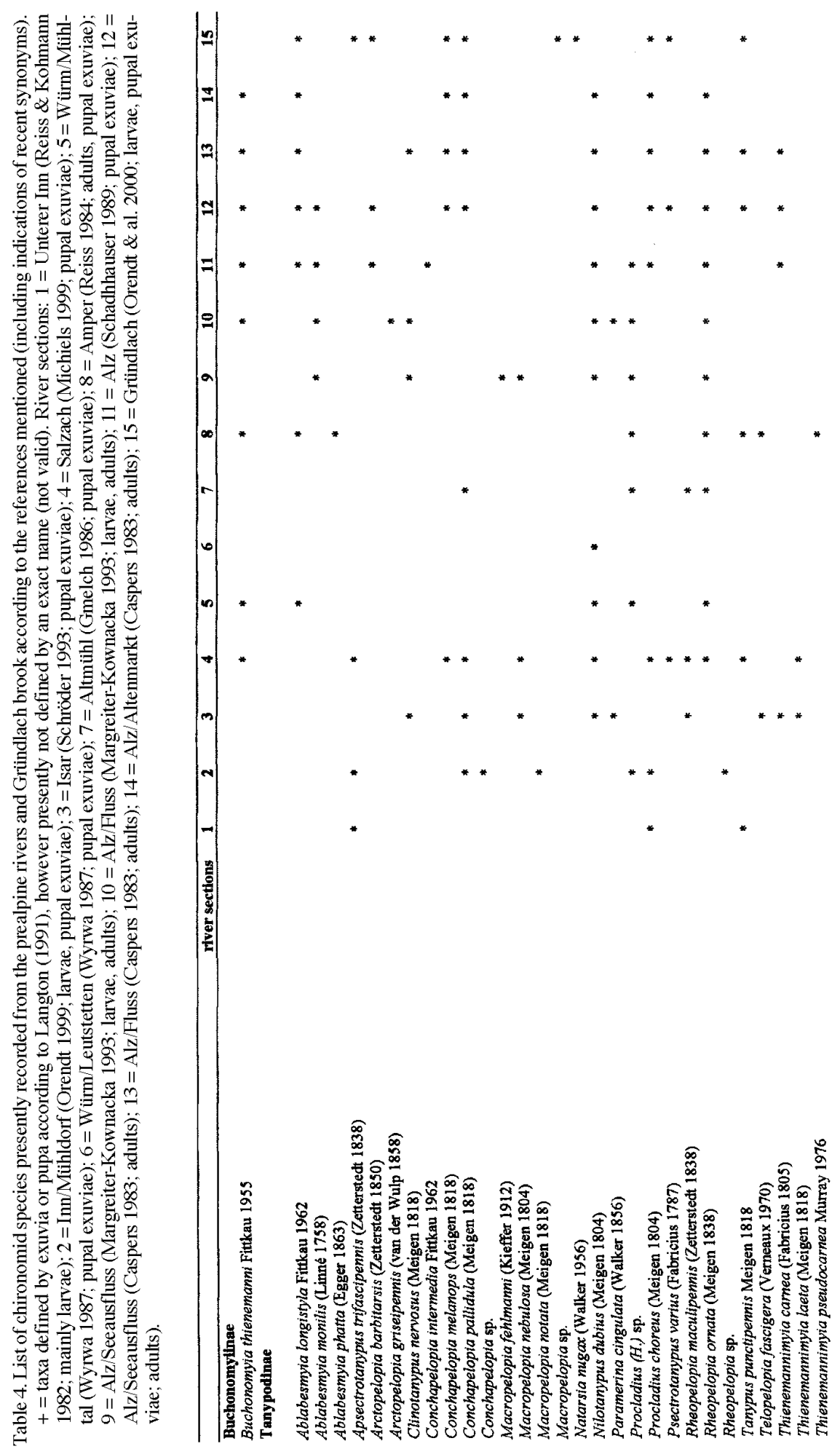


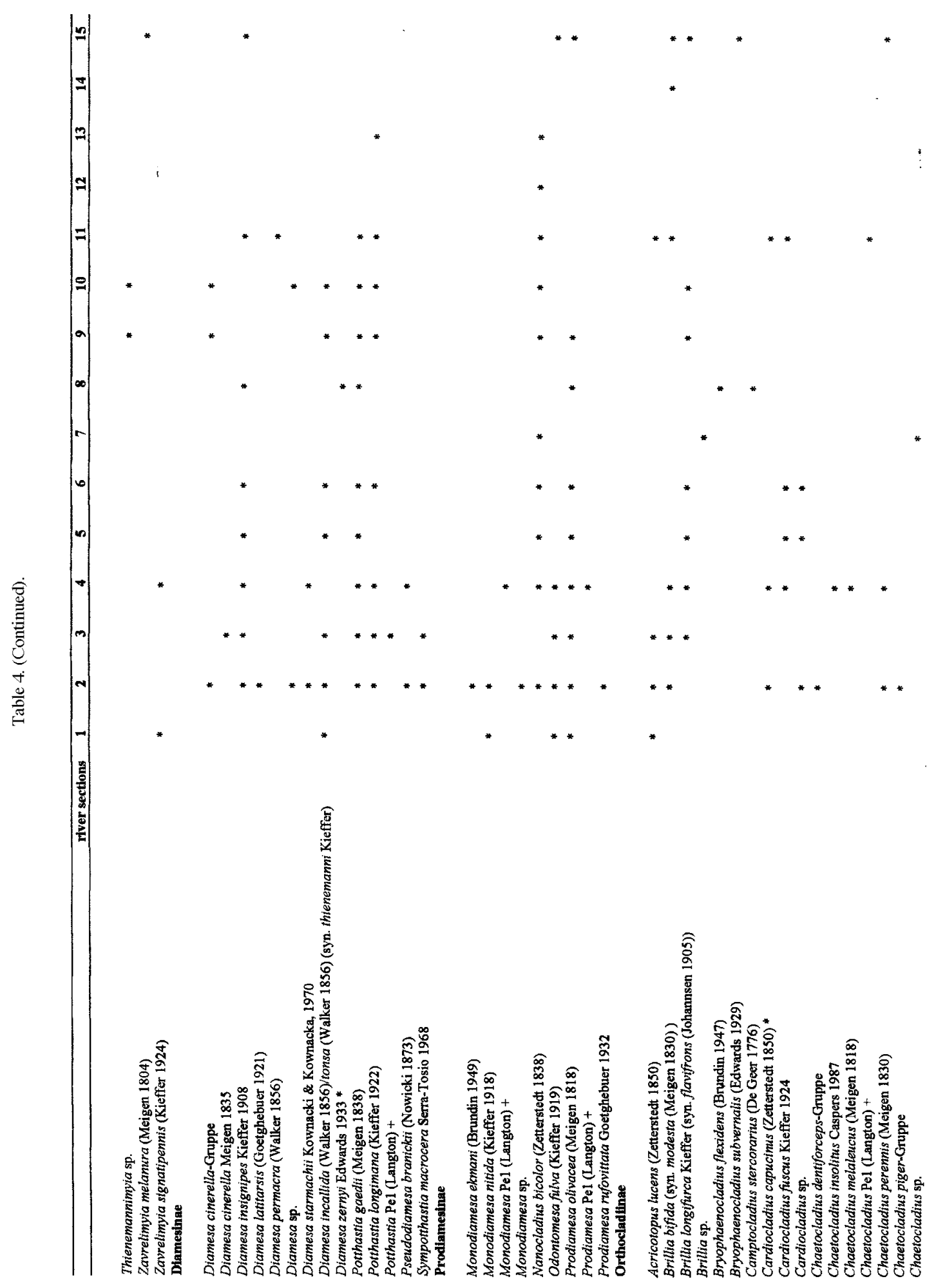




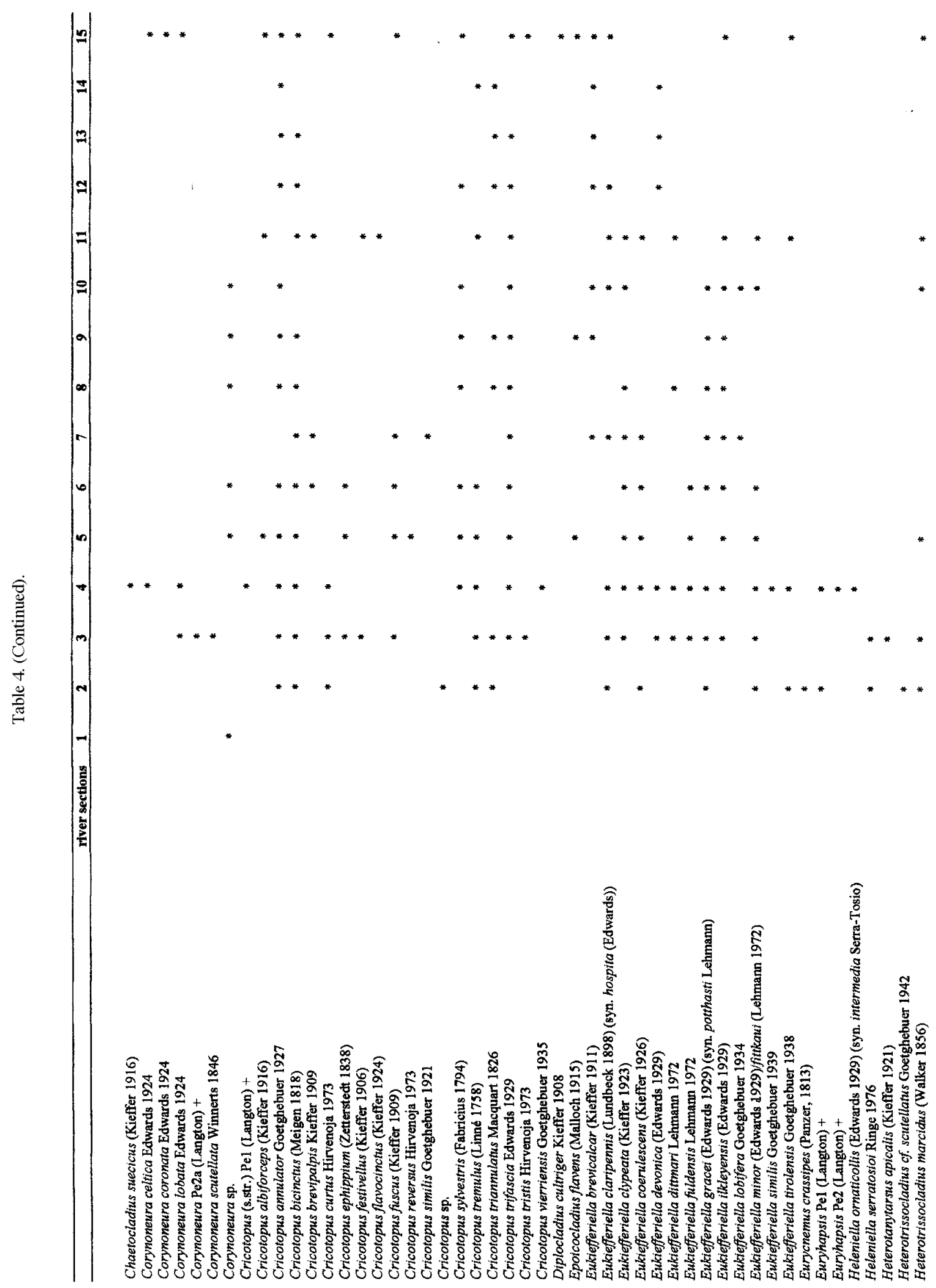




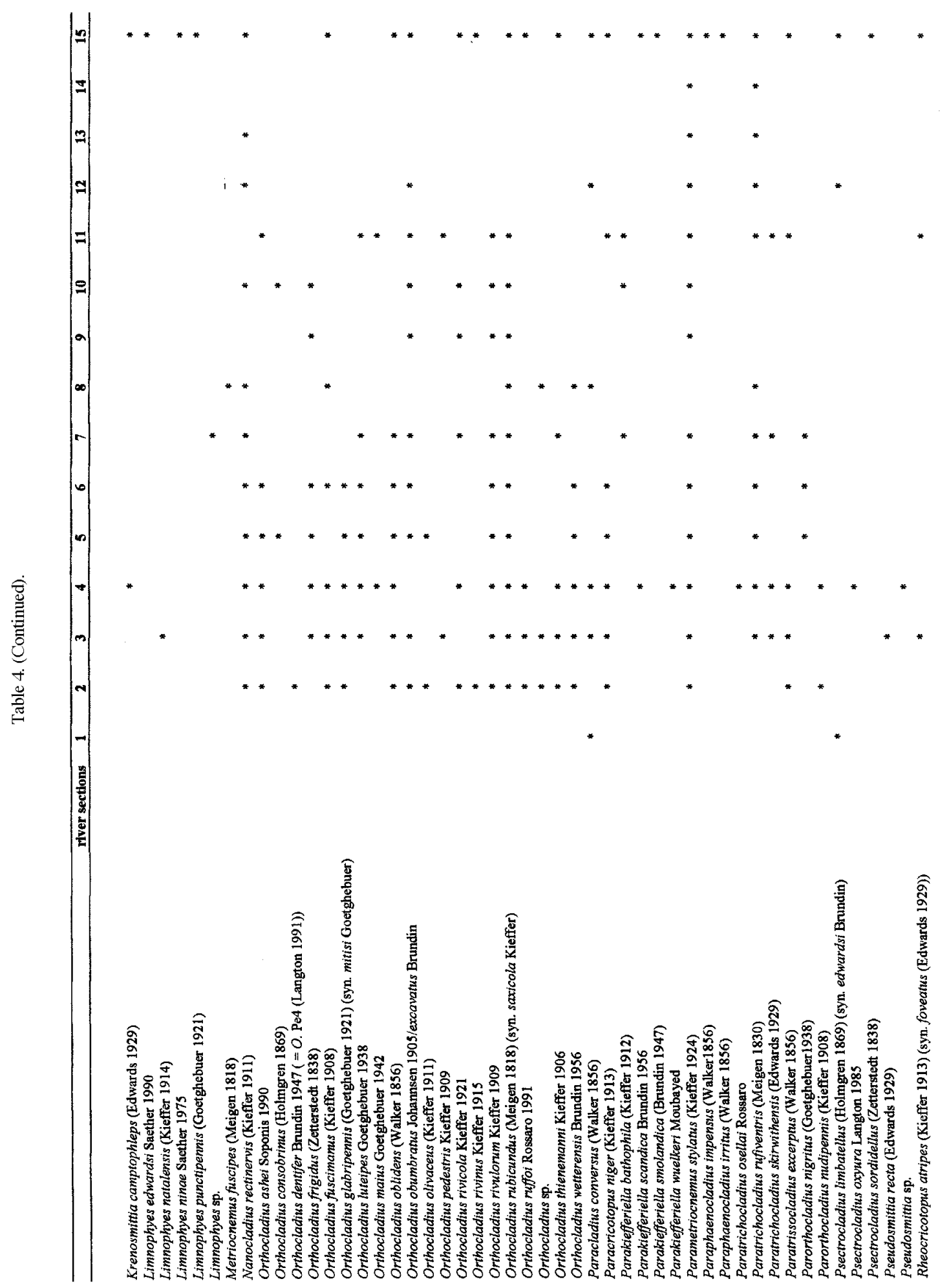




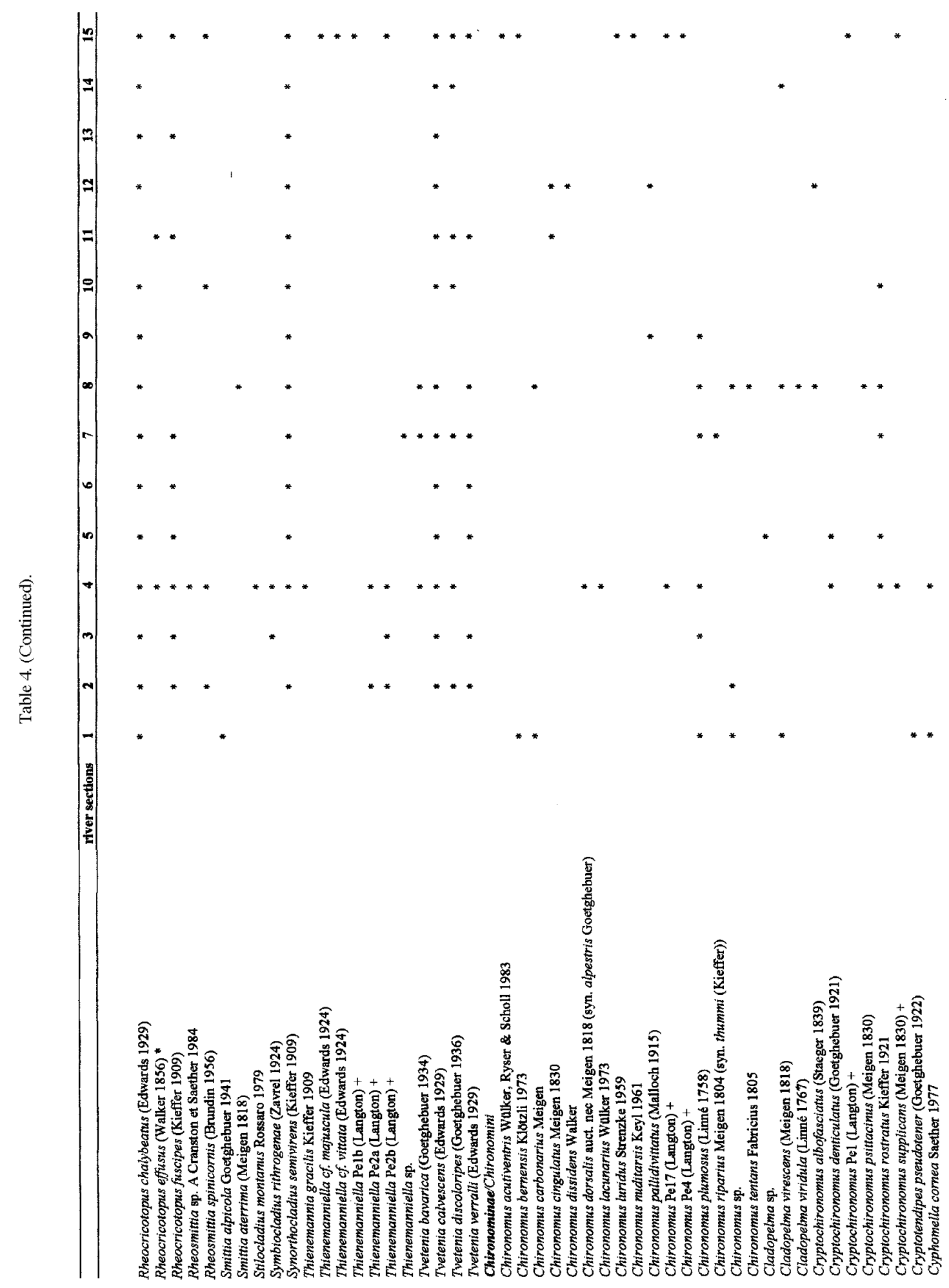




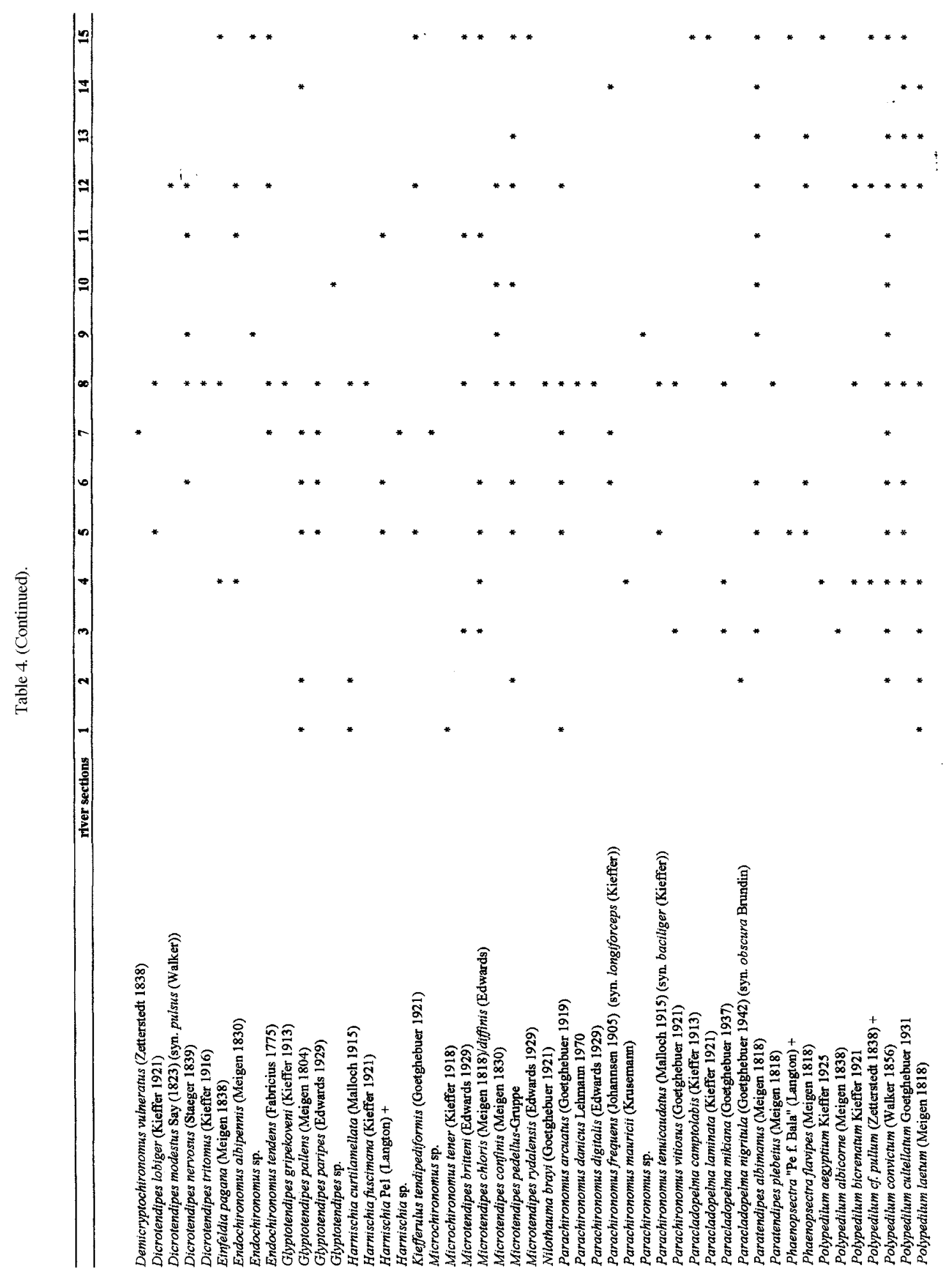




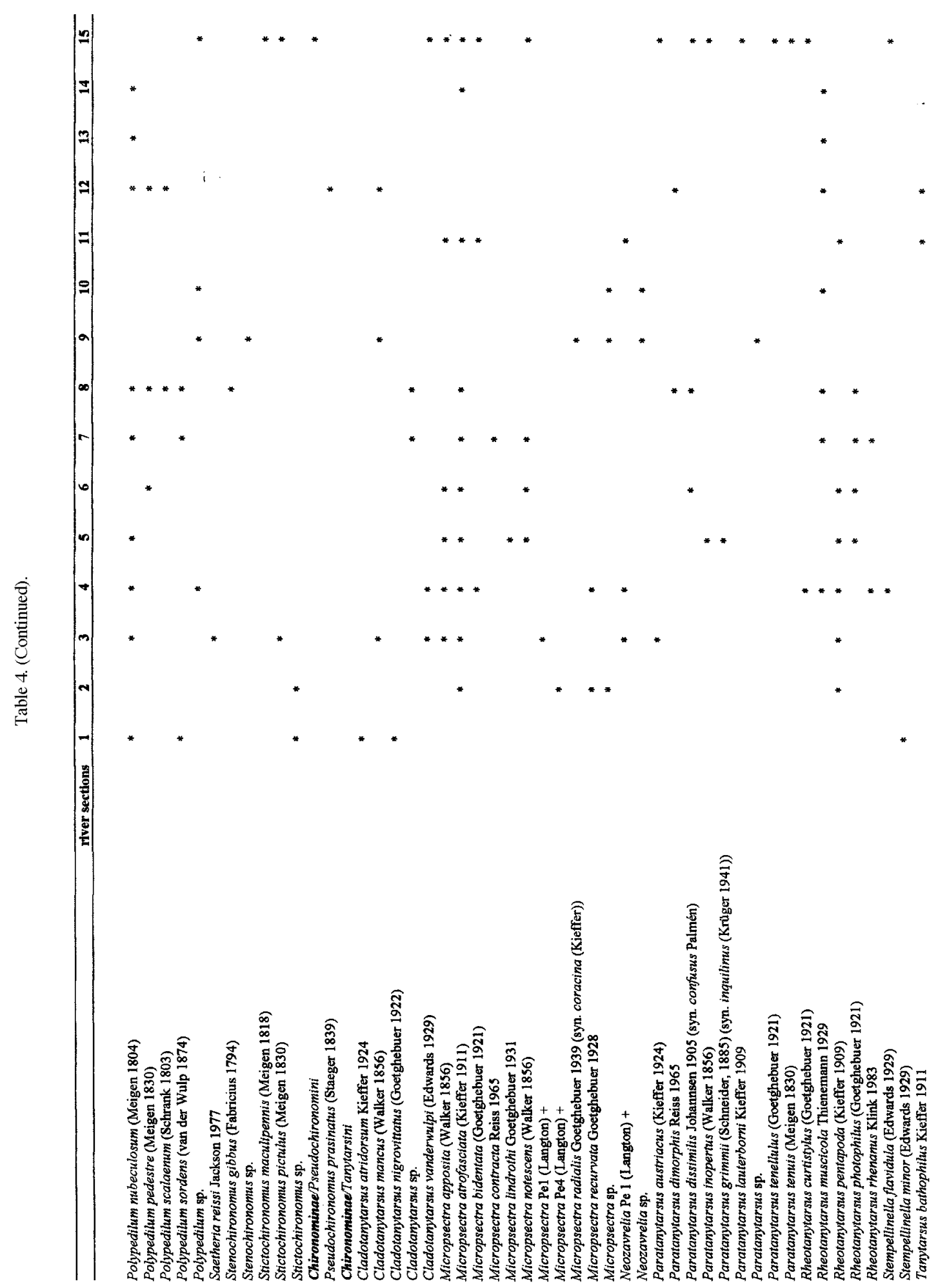




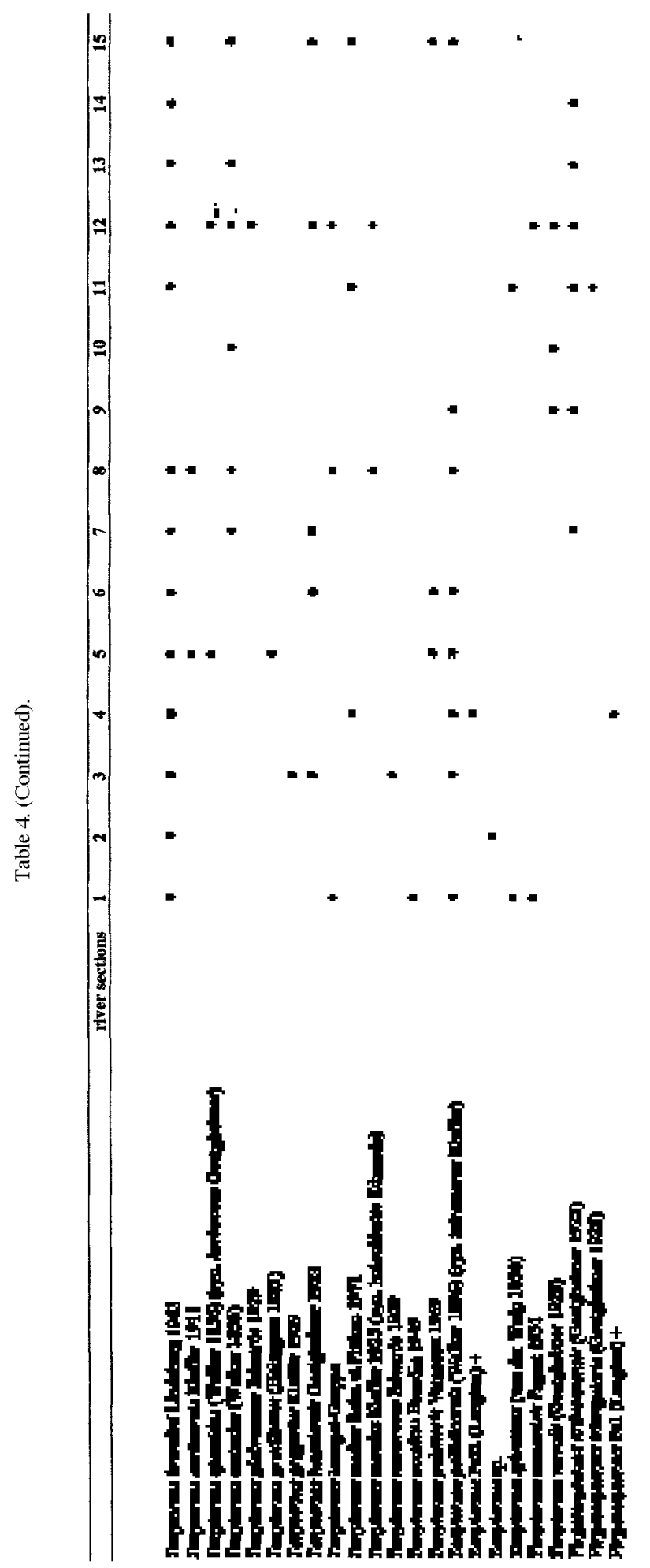


the other river stretches because of its high share of littoral species $(<50 \%$ of the taxa recorded), a low gradient $(0.75 \% \circ)$ and the presence of fine sediments is characteristic. The effect of dams and accumulation of fine organic matter at the ground of the water body can be considered as responsible for a more lacustrine character rather than a potamal one which would be expected here from the natural landscape settings.

The results suggested that the classification of the prealpine rivers corresponds most plausibly to the water temperature rather than to other factors of landscape morphology, although, until now, exact correlations are still lacking. This is in harmony with the conclusions by Rossaro (1992) and Lindegaard \& Brodersen (1995). Reach slope and other morphological factors (e.g. substrate) may be other important factors, apparently, or play a role in some cases. However, the data available so far do not allow satisfying complete interpretation. Biogeographical factors considered by Lindegaard \& Brodersen (1995) and Aagard (1995) can be excluded for the European scale concerning the area of the study, as the chironomid species recorded and evaluated are widespread (after Lindegaard \& Brodersen 1995). The results from the Upper Alz present a special case. The character of the faunistic community changes in longitudinal direction between lake outlet and moraine rupture. This reflects the variety of the landscape: the first section is directly influenced by the lake outlet, summer-warm and without coarse sediment material. Around the edge of the moraine rupture, the coarse sediment material and slope increases give the impression of a pre-mountain river and resembling the morphological character of the Isar or Salzach. Probably, the cold River Traun from the south and inflowing springs may lower the water temperature in this section. This assumption is supported by the changing character of the chironomid community. Similar natural settings can be found in the studied section of the Würm (moraine ruptures), which is the nearest with respect to species composition. A further problem is the difference between the results of the surveys of Caspers (1983) and Margreiter-Kownacka (1993). Following Caspers the share of epipotamal species is higher than the share of hyporhithral ones, which shows the opposite of the results of the second author. A «rhitrhalisation» of the Upper Alz between the first (1983) and the second (1993) survey is not likely as Margreit e r-Kownacka gives methodological reasons for the $\mathrm{d}$ i fferences: Caspers gained his material from lenitic sites, whereas Marg r e i t e r-Kownacka collected in predominantly lotic sites. Apart from this problem of data heterogeneity, it is clear that the Upper Alz is a com- plex and habitat-rich system. It differs distinctively from the other rivers studied, which appears plausible from the morphological settings.

Based on the recorded communities, each river studied was quite distinct. This view is based on the fact that half of all species were found only at one site. The highest level of species-congruence was observed within the various stretches of the Alz (47 \%) (Margreit e r-Kownacka 1993) and between Salzach and Isar (45\%). The congruence between Würm and Alz/moraine was only $28 \%$. However, the (Diamesinae + Orthocladiinae)/Chironominae ratio shows a stronger relation between Würm and Upper Alz.

\section{Conclusions}

The evaluation of the studies presented in this paper exhibits an approach to a community-based typology. $\mathrm{H}$ o w e v e r, a more detailed study is needed in order to elucidate the direct relations between the faunistic types and the morphological and physiographical settings of the rivers. More surveys of prealpine river communities and morphology, and comparisons with rivers of other countries (e.g. Tagliamento, Italy) are required. In particular, it should be important to elaborate to what extent the partly impacted reaches of the Isar and Inn (Mühldorf) affect the natural community. As showed in this paper, chironomids qualify themselves as powerful indicators of environmental factors: the sampling method (exuviae) is very easy (see Wilson 1980, Wilson \& Bright 1973), they can be recorded in every freshwater habitat, high species numbers can be expected, and the ecological profiles of the species are sufficiently known and available (e.g. Moog et al. 1995, Saether 1979, Orendt 1999).

\section{Acknowledgements}

I wish to thank Les Ruse for revising the English language, and Xavier-Francois Garcia, Régis Céréghino, Berthold Janecek, and an anomymous referee for useful comments on the manuscript.

\section{References}

Arscott D.B., Tockner K. \& Ward J.V. 2000. - Aquatic habitat diversity along the corridor of an Alpine floodplain river (Fiume Tagliamento, Italy). Arch. Hydrobiol., 149 (4): 679-704.

Caspers N. 1983. - Die Chironomiden der Oberen Alz (Diptera, Nematocera). NachrBl Bayer. Entomol., 32/4: 97-108.

Fittkau E.J., Colling M., Hess M., Orendt C., Reiff N. \& Riss W. 1992. - Biologische Trophieindikation im Litoral von Seen. Informationsberichte (Reports) Bayer. Landesamt f. Wa s s e r w i r tschaft 7/92: 101-122 (Munich).

Garcia X.-F. \& Laville H. 2001. - Importance of floodplain waters for the conservation of chironomid (Diptera) in a $6^{\text {th }}$ order section od Garonne river (France). Ann. Limnol. - Int. J. Lim., 37 (1): 35-47. 
Gmelch M. 1986. — Zur Ökologie der Altmühl mit besonderer Berücksichtigung der Chironomidenfauna. Master thesis, Techn. Univ. Munich., $111 \mathrm{pp}$.

Habbe K.A. 1994. — Das deutsche Alpenvorland. Pages 439-474 Liedtke H. \& Marcinek J. (ed.). Physische Geographie Deut schlands. Justus Perthes Verlag Gotha.

Kohmann F. 1982. — Zur Struktur, Dynamik und Diversität der benthischen Invertebratengemeinschaften des Unteren Inn. Ph.D. thesis Univ. Munich, $231 \mathrm{pp}$.

Kretschmer W. 1995. - Hydrobiologische Untersuchungen am Tagliamento (Friaul, Italien). Jahrb. Ve r. z. Schutz d. Berg we lt, 60: 87-108.

Lindegaard C. \& Brodersen K.P. 1995. — Distribution of Chironomidae (Diptera) in the river continuum. Pages 257-271 in Cranston P. (ed.). From genes to ecosystems. CSIRO Publications, Melbourne.

Lippert W., Müller N., Rossel S., Schauer T. \& Vetter G. 1995. Der Tagliamento - Flussmorphologie und Auenvegetation der größten Wildflusslandschaft in den Alpen. Jahrb. Ver. z. Schutz d. Bergwelt, 60:11-70.

Margreiter-Kownacka M. (ed.). 1993. — Die Makrozoobenthos-Gemeinschaften der Oberen Alz - Bestandsaufnahme. Institute for Ecometry, Vienna, $36 \mathrm{pp}$

Meynen E., Schmitthüsen J., Gellert J., Neef E., Müller-Miny H. \& Schultze J.H. 1953-1962. - Handbuch der naturräumlichen Gliederung Deutschlands. Bd. 1 und 2. Privately published, Bundesanstalt für Landeskunde und Raumordnung, Bonn-Bad Godesberg, $1339 \mathrm{pp}$.

Moog O. (ed.) 1995. - Fauna Aquatica Austriaca. Catalogue of the ecological classification of the Austrian freshwater species. Edition May 1995. Wa s s e r w ir t s c h a f t s k a t a s te r, Federal Agency for Agriculture and Forestry, Vienna.

Michiels S. 1999. — Die Chironomidae (Diptera) der unteren Salzach. Lauterbornia, 36: 45-53.

Orendt C. 1999. — Mindestwasser-Untersuchung Inn (zwischen Jettenbach und Töging) 1999. Trichoptera, Plecoptera, Chironomidae. Final report for the Water Agency Rosenheim (Upper Bavaria) $1999,56 \mathrm{pp}$.
Orendt C. 2002. - Die Chironomidenfauna des Inns bei Mühldorf (Oberbayern). Lauterbornia, 44: 109-120

Orendt C., Hehl I., Michiels S. \& Colling M. 2000. — Gewässerökologische Wiederholungsuntersuchung der Simmelberg e $r$ Gründlach bei Heroldsberg 2000 im Zusammenhang mit der Verlegung der B2. Final report for the Institute f. Applied Ecological Studies (ifanos), Nuremberg, December 2000

Reiss F. \& Kohmann 1982. - Die Chironomidenfauna (Diptera, Insecta) des unteren Inn. Mitt. zool. Ges. Braunau, 4 (4/6): 77-88.

Rossaro B. 1992. - Chironomids and water temperature. Aquatic Insects, 13: 837-98.

Saether O.A. 1979. - Chironomid communities as water quality indicators. Holarct. Ecol., 2: 65-74.

Schröder B. 1993. - Qualitative und quantitative Erfassung der Chironomidenfauna (Diptera) der Isar vor Munich durch Oberflächendrift unter besonderer Berücksichtigung diurnaler Schlüpfmuster. Master thesis Univ. Cologne, 115 pp.

Schadhauser L. 1989. - Untersuchungen zur Kenntnis der Chironomidenfauna der Alz. Master thesis Univ. Munich, 117 pp.

Schmedtje U. \& Colling M. 1996. — Ökologische Typisierung der aquatischen Makrofauna. Informationsberichte d. Bayer. Landesamtes f. Wasserwirtschaft (Reports of the Bavarian Water Agency) Munich, No. 4/96, 543 pp.

Wildi O. \& Orlóci L. 1986. — Management and multivariate analysis of vegetation data. Eidgenöss. Anstalt f. d. forstl. Versuchswesen, Zürich-Birmensdorf, Reports No. 215, 139 S.

Wilson R.S. \& Bright P.L. 1973. - The use of chironomid pupal exuviae for characterizing streams. Freshwat. Biol., 3: 238-302.

Wilson R.S. \& McGill J.D. 1977. - A new method of monitoring water quality in a stream receiving sewage effluent, using chironomid pupal exuviae. Water Res., 11: 959-962.

Wilson R.S. 1980. - Classifying rivers using chironomid pupal exuviae. Paper in: Murray, D.A. (ed.). - Chironomidae: Ecology, systematics, cytology and physiology. Pergamon Press, Oxford.

Wyrwa G. 1987. - Qualitative und quantitative Erfassung der Chironomidae (Diptera) der Würm durch Oberflächendrift. Master thesis, Univ. Munich, 133 pp. 